\title{
MYTHOS E LOGOS NOS DIÁLOGOS PLATÔNICOS
}

DONALDO SCHÜLER*

Faculdade de Letras

da Universidade Federal do Rio Grande do Sul

\begin{abstract}
RESUMO: Ao contrário do que se pensava no século passado, mythos e logos podem freqüentar o mesmo tempo e o mesmo espaço. Há momentos irracionais no mito; ainda assim, não se queira declará-lo alheio a preocupações lógicas, se consideramos genealogias e a estrutura dos relatos míticos. Para Heráclito, mythos não é desordem, é outra ordem. Os sofistas libertam o discurso (logos) da natureza (physis). Platão subtrai o discurso da autoridade do orador, ao qual os sofistas o tinham submetido. O mito platônico renova a arte de dizer.
\end{abstract}

PALAVRAS-CHAVE: mythos; logos; diálogo; sofistas; Heráclito; Platão.

O conflito entre mythos e logos se reacende no dealbar dos tempos modernos ao Francis Bacon declarar que o acesso à verdade é obstruído por quatro séries de ídolos implantados no intelecto humano: os da tribo, os da caverna, os do foro e os do teatro. Os ídolos da tribo agem como um espelho, deformam a realidade, assemelhando analogicamente o universo à natureza humana. Os ídolos da caverna residem no interior de cada um e encorajam o indivíduo a construir um mundo particular. Os ídolos do foro propiciam a criação de termos, explicações e definições inadequados, bloqueiam o intelecto e causam controvérsias. Os ídolos do teatro criam mundos fictícios tanto na antigüidade quanto no presente. Livrar o intelecto dos empecilhos que barram o caminho às coisas como elas são é o objetivo do instrumento que Bacon coloca à disposição dos que desejam saber, a doutrina do Novum Organon. Na esteira de Bacon, Descartes abre o Discurso sobre o método com a rejeição da cultura livresca, eivada de fantasias, para que se tenha acesso ao que está fora de dúvida, o próprio eu, fundamento de conhecimentos exatos. Augusto Comte divide no Catecismo positivista a história da humanidade em três estágios: o teológico ou ficcional, o 
metafísico ou abstrato e o positivo ou real. Declara provisório o primeiro estágio; transitório, o segundo e definitivo, o terceiro. Afirmando que evoluímos, quer no plano coletivo quer no plano individual, gradualmente do primeiro ao último estágio, encerra os homens dos tempos míticos num patamar que os deixa muito aquém do saber rigoroso. Afetados pela teoria de Comte, helenistas depreciaram a cultura mítica ao compará-la com o saber científico. Assim Eduard Zeller, embora enfatize a peculiaridade do pensamento helênico comparado ao saber de povos vizinhos, declara que a Teogonia de Hesíodo procede de curiosidade infantil (kindliche Wissbegierde) oposta ao método científico (wissenschftlicher Weg) (Zeller, 1963, p. 97). Lucien Levy-Bruhl afirma na Introdução do livro La mentalité primitive que os povos primitivos mostram decidida aversão ao raciocínio, o que se explicaria pelo conjunto de seus hábitos mentais, mesmo que não denotem incapacidade radical de operações discursivas. Baseado no depoimento de um missionário, afirma que nos pechuanas o pensamento abstrato é, por assim dizer, morto. Os estudos feitos por Lévi-Strauss levam a resultados bem diversos. Em todas as sociedades, observa ele, a comunicação se opera em três níveis: mulheres, bens ou serviços e mensagens. Ao estudar o mito de Édipo, considera todas as versões sem esquecer a de Freud. Tanto em Édipo quanto em outras seqüências narrativas, do mito se pode depreender um modelo lógico que tem como finalidade resolver uma contradição. $\mathrm{O}$ mito se desenvolve como uma espiral até que o impulso intelectual que o produziu se tenha esgotado. Conclui que o pensamento mítico e o pensamento científico se produzem amparados pela mesma lógica, que o homem pensou sempre do mesmo modo. $O$ progresso não afetou a estrutura, limitou-se a introduzir novos objetos.

As vozes que tentaram encerrar o mito nas fronteiras de uma época extinta não foram suficientemente fortes para resguardar os tempos modernos de sua presença. O Hamlet de Shakespeare deriva de um fantasma, o pai morto, a verdade sobre os males que afetam a casa real. $\mathrm{O}$ atormentado príncipe representa com suas visões e suas dúvidas um dos traços do homem moderno. Goethe recria Fausto, outro símbolo do homem moderno, que, seduzido pelo saber sem limites, vende a alma ao diabo para ter acesso à parte da existência que com os estudos se perdeu. Nietzche, ao reconduzir à cena deuses banidos, deriva a tragédia de Dioniso, deus que abriga a força, a saúde exuberante, a alegria de viver. Opondo a vida ao império da razão, pensa que os gregos se teriam tornado, na época da dissolução, superficiais, cabotinos, científicos, adeptos da lógica. E é Zaratustra, um eremita, que anuncia a vinda do super-homem, voltado à terra, descrente de esperanças ultraterrenas, inimigo do homem metafísico, racional, 
hostil à vida. Heidegger, adversário da metafísica como Nietzsche, pensa que o homem da razão cartesiana transformou, no princípio dos tempos modernos, o Ser em ente, objeto sujeito à observação, à dominação. É dessa forma que a era industrial, produto do eu cartesiano, prolonga a metafísica. O Ser, esquecido, sobrevive na arte, porque esta, não sendo criação de uma subjetividade genial, se abre à origem que abarca e supera todos os entes. No vácuo produzido pela desdivinização do mundo, o recuo dos deuses é substituído pela reflexão sobre o mito, a arte perece na tirania da estética, que sujeita o que vem das origens aos rigores da observação. No combate à razão, Heidegger busca a verdade na linguagem anônima e na arte. Heidegger redime a idade pré-lógica da depreciação a que desde o início dos tempos modernos foi degradada. Já antes dele Freud procurara a verdade no enigmático teatro de Sófocles e na evasiva linguagem dos sonhos. Devemos entregar Platão à racionalidade metafísica? Retornamos com esta pergunta aos diálogos.

Platão reflete sobre a origem comum de mythos e logos no Teeteto. Teeteto é um jovem talentoso apresentado a Sócrates por Teodoro, venerável professor de geometria, discípulo de Protágoras, ainda que admire Sócates. Sócrates, para testar o jovem, consulta-o sobre o conceito de saber (episteme). Afoito como costumam ser os jovens desamparados das cautelas que a experiência imprime nos velhos, Teeteto dá como resposta o que aprendera de seu mestre: conhecimento é sensação (151 d-e). Não foi difícil a Sócrates reconhecer a matriz da resposta, Protágoras, para quem o homem é medida de todas as coisas (151c152a). Partindo, como de costume, de experiências cotidianas, o ironista põe-se a examinar a resposta. Se o mesmo sopro de vento causa frio a um sem molestar outro, devemos concluir que um só deslocamento de ar é quente e frio ao mesmo tempo? Sendo negativa a resposta, somos levados a separar a coisa das sensações que ela provoca. Sensações merecem crédito? Essa primeira observação distancia receptor e discurso, ainda que respeitável. Sócrates não afirma que o ensino de Protágoras seja falso. Constatado que Protágoras se refere ao homem em geral e não ao indivíduo, a objeção feita não se sustenta. Mas não se trata de saber nesse instante quem está com a razão. Sócrates salienta que um discurso enigmático como o de Protágoras (eniksato) obriga refletir. Esta é a primeira advertência de Sócrates ao jovem. Seria incorreto, continua Sócrates, localizar objetivamente sensações cromáticas produzidas por objetos em movimento. Há cores que existem para os olhos e não em si mesmas. Verificam-se, de outra parte, numerosas experiências que não perduram, cessado o contato com os objetos. Abalado por essa argumentação contundente, declara Teeteto atônito: "Atesto ante os deu- 
ses, Sócrates, que meu espanto é inimaginável ao me perguntar o que isso significa; já há tempo sinto vertigem só de encarar os fatos" (Teeteto, 155c).

Eis o espanto que os sofistas tinham eliminado da relação entre o locutor e o ouvinte. A persuasão do discurso sofístico impunha a recepção passiva, o aplauso entusiástico. Teeteto tem vertigens (skotodinio) ao sucumbirem as bases que lhe sustentavam a confiança. Sombras empanam-lhe os olhos, sombras semelhantes às que obscurecem a visão de quem se surpreende repentinamente diante do abismo. Teeteto percebe-se abandonado pelo discurso e pela realidade. Isso, entretanto, não assinala o fim do saber, marca, ao contrário o princípio. Sócrates adverte que o espanto é a origem (arkhe), não fim da filosofia. Origem não tem aqui sentido cronológico. $\mathrm{O}$ espanto baliza a investigação, assinalando a rota para as descobertas. Espanto é sofrimento (pathos). Pensemos no sofrimento do herói trágico empenhado no desvendamento da verdade. No espanto, comum ao cantor épico e ao pensador, mythos e logos confluem. O espanto fundamenta-os e os instabiliza. Um como o outro têm por tarefa recuperar o mundo que com o espanto se perdeu.

Mito é o canto das filhas da Memória. A palavra da verdade é delas. Ao mito pertencem o mundo divino e o mundo humano, localizem-se no presente, no passado ou no futuro. Mito é a única linguagem autorizada. Os sonhos, o cálculo, o engano, o fantástico têm a mesma origem: as musas. Até a sentença de juízes é dom das musas. As musas assistem a todos os que falam em público. Reis quando proferem sentenças, oradores quando se levantam na assembléia, cantores quando recordam o passado, sacerdotes quando predizem o futuro, todos se alimentam da energia e da habilidade que vêm das musas. $O$ homem e o universo são carregados pelo ritmo ponderado, tranqüilo do hexâmetro. $O$ mito encadeia fatos e gerações. Desdobra-se em narrativas e genealogias. Mythos é narrativa, genealogia. Da origem a cada uma de suas execuções o mythos não é irracional. Como o logos, o mythos recolhe, congrega. Mito é também a construção dos textos, a narrativa, o modo como as partes se articulam, o papel que cabe às personagens, o ritmo, o som, a seleção de palavras, as comparações, as metáforas, o conjunto dos recursos que determinam a materialidade textual.

Na literatura mítica, o vínculo entre mythos e logos não se rompe, embora a desordem se aloje no interior do mythos, incumbido de dominar o turbilhão das sensações desconexas. Fogem ao ritmo ponderado do mythos, a fúria incontrolada de Aquiles, a repentina paixão amorosa de Zeus no Ida, a intervenção de Afrodite na guerra, a matança desnecessária estimulada por Ares, erros de cálculo, desatinos de toda ordem. Nem mesmo a disciplina militar é suficiente 
para conter atos desatinados. Notória é a debandada dos soldados comandados por Agamênon, ao ouvirem o discurso que deveria encorajá-los a combater. O narrador compara o espetáculo a um enxame de abelhas. Poderíamos imaginar cena mais distante da disposição ordenada de soldados? A perturbação do exército não é mais do que reflexo das contradições que minaram a coerência das palavras do chefe, hostil ao mythos de Nestor, proferido, momentos antes, no conselho de chefes. O mythos, a palavra prudente, é contestada pela desordem, pelo caos. $\mathrm{O}$ mythos também é ameaçado como estrutura narrativa. $\mathrm{O}$ enredo de obras como a Ilíada e a Odisséia é conturbada por tradições contraditórias encadeadas e sobrepostas, celeiro em que se abasteceu a teoria da autoria múltipla, numa época em que se exigia que a narrativa estivesse subordinada à autoridade de um narrador. Não se podem elidir tensões nascidas no corpo do mythos dentre as razões que o levaram ao descrédito.

A separação de mythos e logos ocorre nos aforismos de Heráclito. Mas Heráclito não interpreta mythos como irracionalidade. Para Heráclito mythos não é desordem, é outra ordem, a ordem rejeitada. Expulsa Homero e com ele, a poesia oral, o canto das musas, o hexâmetro, as profecias, a aparato divino, a submissão ao canto, a abundância, a narrativa, o mundo regido por Zeus. O lugar reservado às musas é tomado pelo logos, discurso sem emissor nem receptor, eterno, autônomo, fundamento do universo. Para ter acesso a ele, Heráclito convoca o logos individual. Em lugar do canto amplo, o aforismo, expressão do logos individual aberto ao outro. Em lugar de Zeus, o deus dominador, guerreiro, Heráclito elege um deus sábio, um que fala pouco, que fala tortuosamente, que propõe enigmas, Apolo. Apolo não domina. Apolo conta com a inteligência, a responsabilidade de quem recebe os enigmas. Os enigmas de Heráclito têm essa origem. A linguagem desprendeu-se da autoridade divina e dos referentes. As palavras não dizem as coisas como elas são. A linguagem está incuravelmente enferma. Por isso é preciso tratá-la. Heráclito produz textos para serem lidos e refletidos, textos que não fecham a questão, que abrem, que fazem pensar. Neutralizada a tradição, a poesia é sustentada por outras bases, a invenção, o trabalhar com palavras e sons. Heráclito incorpora recursos da poesia lírica, embora combata Arquíloco. Evoca Apolo, embora proponha um fundamento que exclui as divindades míticas. Reflete sobre questões levantadas pela epopéia, embora condene Homero. Tece genealogias, não de entes, mas de palavras. Palavras se acasalam com palavras e geram outras palavras, linhagens fecundas que se enredam na produção discursiva do Ocidente, linhagens, de que os aforismos de Heráclito constituem um momento privilegiado. Como se vê, não é simples sepa- 
rar mythos e logos, nem para Heráclito. Heráclito é afetado pelo discurso que recusa. Preserva-o reelaborado. Absoluto é agora o logos. É ele que sustenta os discursos, também o discurso mítico.

Opondo-se a Heráclito, os sofistas propugnam para o logos um domínio só dele, livre de hipotéticas determinações da natureza (physis). Liberta a linguagem da natureza, é-lhes possível elaborar uma filosofia política desvinculada de organizações naturais como a família, origem da genealogia, coluna vertebral da narrativa mítica. Ao separarem a linguagem (nomos, $\log o s)$ da physis, os sofistas começaram a examiná-la com o cuidado que os físicos tinham dedicado à physis. Nasce a gramática e a retórica. Fundamento é agora o logos verbal, alicerce do estado, de tudo. Em lugar do logos anônimo de Heráclito, que supera e congrega todos os discursos, pontifica o emissor autoritário. Este arrebata a autoridade que no discurso mítico cabia às musas. Os aforismos, que estimulavam a produção intelectual, são repelidos em benefício de uma ordem em que as idéias se entretecem compactas para sufocar a reflexão. Em lugar do espanto comparece a persuasão que penetra no corpo do receptor como um pharmakon, uma droga inebriante. $\mathrm{O}$ pharmakon da persuasão, investida de poder irresistível, corta acesso ao referente, priva da faculdade de julgar.

Descontente com a autoridade conferida ao discurso, Platão volta a submeter as teses dos sofistas a novo exame: a relação nomos / physis, a autoridade de quem fala, a função do discurso, o papel do receptor. Contestada a oposição nomos / physis, cabe a Platão examinar a natureza da linguagem e a possibilidade que ela possa oferecer para recuperar o que com a cisão se perdeu.

A Apologia não é só a defesa de Sócrates, é também a exigência ao respeito de um discurso não contaminado pelas leis da retórica. Se as regras inventadas para embelezar o discurso tinham barrado o caminho ao saber, importavalhe derrubá-las para restabelecer sendas à verdade mesmo diante da morte. Em lugar do emissor iluminado dos sofistas, Platão propõe aos juízes de Atenas um orador que não sabe e que por isso convoca todos para as fileiras dos que buscam a verdade mesmo que isso lhes traga a morte. A presença instigante de Sócrates condena recursos retóricos ocos arquitetados para confundir e não para esclarecer.

O espanto desaloja a persuasão na peça que o escritor atribui ao mestre que não escrevia. Não é espantoso que o réu, acusado de crimes graves, ouse dirigir-se em linguagem vulgar a juízes, sofisticados além de sofistas, linguagem das praças e das casas de Atenas? Em vez de rogar clemência, Sócrates denuncia 
a cegueira dos que têm a vida dele em suas mãos. Isso não espanta? Coerente consigo mesmo, Sócrates preza a verdade mais que a vida. Platão cria personagens como o fizeram Homero e os tragedistas. Cria discursos que os identificam, sendo a Apologia o primeiro da série.

Ao recuperar o espanto eliminado pela persuasão na retórica dos sofistas, Platão quer que ele estale não diante da natureza como outrora, mas diante do discurso. Para renovar, entretanto, o movimento do saber, urgia romper a barreira construída pelos sofistas, o discurso compreendido como uma corpo.

O discurso, investido do poder de ressuscitar, desperta mortos ilustres nos diálogos platônicos: Pitágoras, Parmênides, Protágoras, Górgias... Chamando da morte para a vida, o discurso de Platão age como um pharmakon que restaura a linguagem desvirtualizada. Sendo a linguagem uma droga (pharmakon), requerem-se os serviços de um médico (pharmakos) para administrá-la. A prática logográfica ensinou que o locutor pode agir sem a presença do autor, o pai do discurso. $O$ réu, dando a entender que lhe pertence o discurso escrito por outro, torna-se culpado de parricídio à sua maneira. Fiel à tradição logográfica, Platão escreve um discurso para Sócrates, um Sócrates já morto. Sócrates morre como linguagem falada e renasce como linguagem escrita, passagem em que não se perde o vigor do instrumento verbal de uso diário. No Fedro o discurso memorizado desaloja a palavra viva, na Apologia, ao contrário, a linguagem dá vida a Sócrates, um morto. Adversário do discurso autoritário dos sofistas, Platão não fala, delega o discurso a outro, a Sócrates. Como Sócrates não existe mais, Platão pode reinventá-lo. Começa assim a atividade ficcional de Platão, banindo aqui como alhures os poetas para renovar a poesia. Nietzche diz que Platão se distingue na mistura de estilos. Não se esqueça a mistura da linguagem erudita e da vulgar. Essa não é a linguagem das musas, que Platão combatia sistematicamente, é a reinvenção da oralidade que lembra a espontaneidade dos cantos heróicos. Se por logos estendemos o esforço para alcançar o saber, fica para o mythos a renovação da arte de dizer. Esse discurso, que ataca a retórica, inscreve Platão na categoria dos logógrafos excepcionais. Não há originalidade em escrever discurso ficcional. Górgias e Tucídides dentre muitos outros já o tinham feito. Novo é o procedimento de Platão, a enérgica rejeição da retórica. Adversário dos sofistas, Platão decide procurar a verdade num lugar em que ela não está, o tribunal, reduto da retórica. A verdade é a meta que leva Sócrates a falar. Para Sócrates, a verdade, sempre evasiva, esconde-se atrás da construção verbal. Importa desmascarar os sofistas. Onde? No tribunal. Como dizer que ao referente não se tem acesso, se o referente está diante dos olhos e fala? Se Sócrates é capaz de provar 
a falsidade das acusações feitas contra ele, rui o discurso sofístico. Há verdades além do discurso, essa é a tese do Platão. E a verdade aí está, o Sócrates autêntico, denegrido pelo discurso. Sócrates: "Eu vos direi toda a verdade". Não se espere que Sócrates esgote a verdade nesse momento. Nem mesmo uma vida inteira é suficiente para conduzir às coisas mesmas. Mas a verdade começa no que está ao nosso alcance. Essa é a base do método platônico. A investigação, iniciada em evidências comuns, avança em direção ao que está distante numa encadeamento sem fim. Esse é o processo dialético que se opõe à persuasão sofística. O discurso elaborado, ápice das criações literárias na opinião dos sofistas, não passa de exercício escolar aos olhos de Sócrates. Para renovar o discurso impõese o recuo ao discurso da infância, a linguagem de todos os dias. Declarando-se ignorante, Sócrates despe o discurso dos ornamentos com os quais os sofistas o tinham embelezado. O discurso escrito por Platão para Sócrates afronta os preceitos de Górgias. A recusa da linguagem rebuscada, privilégio de poucos, abre as portas à democratização do saber. Os interlocutores dos diálogos platônicos falam do jeito que sabem.

Que diz a acusação? Ela sustenta que Sócrates perverte a juventude e que introduz deuses novos na cidade em desobediência às leis de Atenas.

Sócrates divide, para começar, os acusadores em duas categorias: os antigos e os recentes. Quanto aos antigos, ele afirma que há já trinta anos um certo Aristófanes escreveu uma comédia cujo protagonista é um Sócrates ridículo, investigador da natureza e adorador das nuvens. A comédia contribuiu para formar uma multidão de acusadores anônimos. Como se defender em algumas horas de uma acusação que se arrasta por trinta anos? $\mathrm{O}$ réu acusa o sistema judiciário.

Dentre os acusadores presentes ele destaca um certo Anito, um político. Pergunta-lhe: Outro dos atenienses perverte juventude ou somente ele, Sócrates? Sócrates, é a resposta. Não há outro. A resposta arranca louvores do réu à cidade de Atenas. Que mal pode causar o vício de um só à virtude de todos?

Contra a acusação de introduzir ilegalmente deuses na cidade, Sócrates alega um mal-entendido. Referia-se com freqüência a um certo daimonion, uma voz interior que o advertia na iminência de atos reprováveis.

Não foi a impiedade mas o fervor religioso que lhe trouxe dissabores, pondera. Um amigo tinha consultado o oráculo de Delfos para saber quem era o mais sábio dos homens. Sócrates, respondeu o oráculo. A resposta délfica, que lhe merece todo o respeito, o coloca diante de um enigma que o leva a interrogar 
todos os que sabem: notadamente, políticos e poetas. Os interrogados, menos piedosos que Sócrates e mais vaidosos que ele, não entenderam o sentido das perguntas que lhes causavam embaraços constrangedores, eles, que se tinham por sábios.

Mítico, como se vê, é o fundamento do empreendimento dialético. A mensagem délfica, lembrada na Apologia, afeta toda a vida intelectual do inquieto questionador. Consulentes afoitos, conduzidos mais pela paixão do que pela razão, arruinaram-se com interpretações apressadas. Mesmo Édipo. Sócrates, atilado, percebe a complexidade da sentença que lhe trazem de Delfos. Confrontando-a com o que ele próprio sabe de si, surpreende-o o paradoxo que lhe leva a tranqüilidade, início de pedregoso e trágico caminho. Temos aí outra semelhança de sua trajetória com a de Édipo. O oráculo obriga Sócrates a refletir sobre a fala tortuosa de Apolo, início da carreira do pensador, intérprete de falas, a de Apolo e a de outros.

Os acusadores consideraram as lições de Sócrates veneno que corrompe a juventude ateniense e tratam de eliminá-lo. À maneira de um bode expiatório, portador dos males da cidade, Sócrates deixa o tribunal para trilhar o caminho da morte. $\mathrm{O}$ carrasco lhe administra significativamente veneno. A homeopatia política combate um veneno com outro para a purificação da cidade.

Os atritos causados pela investigação, incontornável como o destino, levam Sócrates à morte, vestíbulo, ao que espera, de mais serena investigação. A história confirmou-lhe a esperança. As questões que o inquietavam atravessaram fronteiras e séculos. A cidade de Atenas, lugar em que a investigação foi violentamente interrompida, lhe teria oferecido melhores condições, fosse administrada por filósofos de acordo com padrões por ele idealizados. A Apologia aponta mythos e logos confundidos.

Contra o autoritarismo dos sofistas, a investigação. Sócrates se comporta como um histor, um explorador de textos a exemplo de Heródoto. Depois da Apologia, a defesa avança pelos diálogos que não abandonam as questões que Sócrates, por falta de tempo, não pode desenvolver. Contra o discurso limitado, os diálogos, discurso sem limites.

Sócrates só fala quando desafiado. Os diálogos surgem como resposta. Da pergunta sobre a natureza da virtude nasce o Mênon. A investigação da justiça origina a República. O banquete emerge do desejo de saber o que é o amor. Crátilo responde a dúvidas sobre a linguagem. Os diálogos buscam uma esfera que supera o discurso sofístico. 
A época é de crise. Atenas, derrotada e enfraquecida, sente os efeitos da devastadora guerra do Peloponeso. Sofistas orientam a educação em Atenas e na Grécia. Já não há certeza de nada. Poesia, tradição, justiça, forma de governo... O que não suscita dúvida? Vivendo intensamente o conflito, Platão não se comporta nostalgicamente. Recolhe sem servilismo o patriotismo cultural de outras gerações e toma as decisões que o momento exige, centrando os diálogos em Sócrates, um homem sem apego a dinheiro, prestígio ou favores. Os sofistas optam por uma solução mais simples: verdadeiro é o prático, o aparente. Platão, em conflito com o aparente (doxa), precavido contra truques de retórica, requer que a validade do que quer que se afirme seja demonstrado.

A linguagem, floresta em que se perderam poetas e sofistas, não é o menor dos problemas que o momento propõe. Platão os enfrenta no Crátilo. Sócrates entra num debate em andamento. Crátilo, discípulo de Heráclito, afirma a adequação dos nomes aos entes nomeados, posição que reproduz só em parte a doutrina do mestre, visto que o pensador de Éfeso já alertara enfaticamente para as informações inexatas veiculadas pelas palavras. Hermógenes contesta a doutrina de Crátilo, afirmando que nomes são atribuídos a seres por convenção. Esta é a doutrina triunfante na Atenas do $\mathrm{V}$ século, época em que as leis provinham de um legislador individual como Sólon ou de decisões da assembléia. Sócrates é levado a pronunciar-se sobre as posições excludentes. Argumenta com uma hipotética linguagem dos deuses, precisa. Se a tivéssemos, teríamos que aceitar a teoria de Crátilo. Como a linguagem divina não nos ampara, não há como contornar o debate. Atento ao que afirmam os dois contendores, Sócrates lembra o homem-medida de Protágoras. Sabendo que seres justos podem parecer injustos e que seres injustos podem parecer justos, não lhe parece correto que se fale em homem no singular, já que a sensatez ou a insensatez dos observadores afeta a percepção. Com isso vai-se a autoridade que os sofistas atribuíam ao emissor. Paralelamente a nomes verdadeiros e falsos, existem ações adequadas e impróprias. $\mathrm{O}$ ato de cortar e de queimar estão objetivamente determinadas, sua execução não depende do nosso arbítrio. Pode-se cortar uma pedra, mas não se pode queimá-la. $\mathrm{O}$ discurso não pode tudo como queriam os sofistas. $\mathrm{O}$ discurso compreende o nomear, uma ação (praxis). Atue-se por palavras ou por atos, a natureza do nomeado requer atenção. Corta-se com a faca, tece-se com a lançadeira, nomeia-se com palavras. O nome é, portanto, instrumento a serviço da ação. Como a lançadeira ou a faca, produto de um artesão, os nomes pertencem à lei (nomos), e esta os oferece aos usuários. Como a lei não vem dos deuses, nem da natureza, deve-se concluir que seja produto de um legislador (nomothetes). 
Este pode ser um só ou uma coletividade, pode ser representado por poetas ou por homens privados. A palavra age mas não sem considerar a natureza do objeto.

Sócrates passa ao exame de nomes com o fim de verificar se eles são adequados aos referentes. Percebe-se uma ponta de ironia no exame detalhado de etimologias fantasiosas. Hektor (Heitor), nome do soldado responsável pela defesa de Tróia, se derivado de hektor (o que segura firme, defensor), está correto. Não menos correto é o nome de Agamênon, chefe supremo das forças atacantes, derivado de agastos (admirável) e de meno (perseverar). O nome assim composto explica o caráter do soldado que persevera admiravelmente num cerco de dez anos. Nomes como os desses dois heróis gozam de prestígio em virtude de Homero, o poeta que os inventou. Outros nomes - entre eles Eutykhides (Felizardo) ou Sosias (Salvador) - exprimem apenas o desejo dos pais. Nomes há que encerram concepções falsas. Os que chamaram seres eternos de theoi (deuses), nome derivado de theo, "correr", não alcançaram, iludidos pela aparência, a permanência dos entes divinos. Os muitos aspectos que se devem observar na formação das palavras minam a autoridade de quem fala.

Afastado do mundo pelo espanto, o homem recorre a nomes para reaver o perdido. O resultado de longo esforço, guardado em obras literárias e no vocabulário de todos os dias, não facilita o trabalho dos que buscam. $\mathrm{O}$ homem comporta-se como medida ao nomear, medida insegura, visto que os nomes revelam mais dos interesses e das concepções dos inventores de nomes do que da natureza dos objetos.

Convém que o artesão de nomes (onomatourgos) domine a arte (tekhne) de forjar nomes à maneira de outros artesãos. Para realizar satisfatoriamente o seu ofício, impõe-se que o legislador contemple a forma (eidos). A qualidade das criações (lançadeira, lira, navio) é apurada pelo usuário (tecelão, citarista, piloto). Indicado para julgar a propriedade dos nomes é o experimentado em interrogar, o dialético, cuja atenção está voltada para objetos que escapam do palpite e da incerteza. Visto que a atividade de quem examina a propriedade dos nomes não tem fim, ela atravessa toda a atividade literária de Platão. Platão consagra a vida ao exercício de examinar e de propor nomes.

Para instaurar o diálogo, Platão não evita o parricídio. O parricídio - Platão tinha o Édipo rei diante dos olhos - o arrasta à tragédia. Isso ocorre no Sofista, diálogo em que o Estrangeiro, discípulo de Parmênides e Teeteto, um sofista platônico, se encontram. O Estrangeiro, filho espiritual de Parmênides, que nunca fa- 
lou (foi falado mas não falou) é constrangido a falar. Maieuticamente conduzido por Teeteto, o Estrangeiro aprende a falar. Ele sabia ouvir, sabia repetir o que ouvira, mas não sabia falar. Ele que sabia dizer uma coisa só, que o ser é e o não-ser não é, é obrigado a refletir sobre a múltipla banalidade cotidiana: pesca, agricultura, comércio, caça... O discurso, atravessando a Ática viva e ativa, encena uma paisagem rica e variada. Com que finalidade? Perceber as leis que regem atividades caoticamente dispersas na vida cotidiana. Isso não desvia Teeteto, o "parteiro", do objetivo estabelecido, definir o sofista, ou melhor o discurso sofístico. O sofista é produto do discurso que pratica. Definido o discurso, definido está o sofista. O Estrangeiro não o é só para Atenas. Habituado a refletir numa coisa só, o ser, estranho e penoso lhe é o mundo que o rodeia. Teeteto o obriga a percorrer direção contrária a do escravo da caverna. $O$ escravo, que só conhecia trevas, espantase quando vê as coisas que projetam formas na rocha sombria. O Estrangeiro, que vem da luz, mostra-se atônito ao deter-se em sombras pela primeira vez, e sombras de sombras, o discurso sofístico. O Estrangeiro se move como se fosse trabalhosamente empurrado do útero materno para a realidade cotidiana. Artes da maiêutica! Expulso do conforto uterino, vencido o caminho, exclama perplexo : o não ser é ( to me on einai), dando-se conta da enormidade do crime, o parricídio. Parmênides, o pai idolatrado que negara existência ao não ser, acabava de ser mortalmente atingido pela lâmina da língua de um discípulo seu.

Em lugar da exposição oral, praticada pelos sofistas, Platão escolhe a escrita. O discurso oral, no momento de acontecer, cria a ilusão do discurso único, pleno, eterno: o discurso das musas e o discurso dos sofistas. Na escrita, o discurso se circunscreve, se objetiva, se limita, se fragmenta. Quem é o enunciador da página escrita, na qual textos de muitas origens se embaralham à vista do leitor? $\mathrm{Na}$ ausência do autor e das circunstâncias em que o texto foi produzido, a escrita, oferecida a leitores variados, evade-se do eixo de comunicação, pois as relações incessantemente se alteram. Ao expulsar poetas, ao afrontar sofistas, Platão recusa o enunciador autoritário, singular, instaurando enunciadores em lugar dele, muitos. Surge o diálogo. Não se diga que Platão subordina de fato os diálogos a Sócrates. Sócrates, enquanto personagem, sofre as vicissitudes das criações literárias. De diálogo a diálogo, Sócrates muda. Sócrates não é um só, Sócrates é muitos. Enumeremos alguns: o Sócrates matemático, o Sócrates místico, o Sócates irônico, o Sócrates cômico, o Sócrates lírico, o Sócrates político... Onde está o Sócrates histórico? Perdeu-se atrás das muitas máscaras inventadas como as que revestem Napoleão ou Hitler literariamente produzidos. Poderíamos pensar em verdade (aletheia) como um efeito só de linguagem? Aparentado com phaos e phaino, 
o falar, oral ou escrito, ilumina. A iluminação, variada, imprevisível, vem da palavra. Fora dela, o silêncio, a sombra, a disponibilidade ou a rigidez do que não muda. Quando falamos ou escrevemos, dizemos o que já foi mil vezes dito e falado, no entanto, o que dizemos nunca foi dito antes de nós nem o será depois. O discurso origina, alimenta, desconstrói discursos e idéias, as platônicas e as demais. O discurso carrega as idéias. Soltas no mundo idéias não há, à semelhança do Eros do Banquete, que não conhece existência se não a literária. Quando a Justiça de Parmênides tomou o lugar das musas, o discurso mudou de dono. Platão derruba as musas e a Justiça do lugar de eminência, distribuindo o discurso entre interlocutores. Ainda resta Diotima. Mas Diotima, reveladora e limitada como os demais, é lembrança mítica, atraída no Banquete ao jogo das interlocuções. O golpe é definitivo. Em lugar do discurso autoritário de um, a fala plural de muitos. É verdade, Platão privilegia Sócrates no Banquete e em outros diálogos, embora se trate de um privilégio equívoco. Platão, o ironista, não se poupa nem a si mesmo. Ele não se limita a demolir o discurso de Agatão. Demolindo-o, estabelece-o como negado. Como poderíamos ter noção do discurso bem sucedido, se não possuíssemos o discurso falido de Agatão? Conclusão: todos os discursos do Banquete permanecem de pé. Todos são limitados. Como atuar fora de limites, fora das sombras? Sem limites, como falar, como saber? E a fala de Sócrates? No Banquete ela não existe. Sócrates disse que não proferiria discurso e não o fez. Em vez do discurso, a poesia reinventada, a sedutora fala de Diotima. Qual o privilégio de Sócrates? Nenhum. Colocado estrategicamente no fim do diálogo, ele silencia. Silencia por quê? Porque, o que Sócrates gostaria de dizer, não é dizível: a fala rigorosa (episteme). Sócrates, ao passar a palavra a Diotima, reconhece a própria ignorância. Ele é coerente, não sabe e o demonstrou.

Platão queria para a filosofia um método e uma linguagem que tivessem o rigor da matemática e cujos fundamentos fossem mais gerais que os dela. Em matemática não há discussão, há demonstração. A linha é o caminho mais curto entre dois pontos. Discutir o quê? Não se deveria definir a Justiça com o mesmo rigor? Enquanto não o fizermos, viveremos enredados na estratégia dos sofistas. $\mathrm{O}$ que é justiça em Corinto? O que é justiça em Esparta?... As oposições movimento / repouso, outro / mesmo, ser / não-ser estão matematicamente corretas. Cada uma delas é, assim como a linha é. Mas isso demite as idéias como essências. Concreto é o discurso. O discurso é fundamento. Sem discurso some tudo, até a matemática, principalmente ela, ela em primeiro lugar. Permanece o projeto platônico, contrário ao dos sofistas: atravessar o discurso. Projeto louvável, contudo projeto. 
Devolvendo o logos à physis, Platão ergue o logos às categorias superiores sem o qual elas se perderiam na desordem. Como no sistema de Heráclito, o logos une os contrários sem excluir ser e não-ser, coexistência impossível para Parmênides e Górgias, entretanto indispensável ao movimento do universo e à flexibilidade do discurso.

Da epopéia até aqui, o mythos incorporou a tragédia, reelaborada por Platão no processo de suas investigações sem esquecer recursos da narrativa épica. Combinação de reflexão filosófica, tragédia e epopéia temos em Timeu, peça de uma tetralogia projetada e não concluída. $\mathrm{O}$ início do diálogo alude a um livro que não houve, parece a República mas não é, é Platão refazendo o que fez. O diálogo que não houve, o diálogo imaginário, é a primeira peça da trilogia. Nela se tratou de assuntos já analisados na República, com ligeiras modificações: classes sociais, exército, comunidade dos bens, educação, casamento. Feito o resumo da constituição do estado ideal, Sócrates propõe que se fale da ação do exército, tarefa que ele passa a outro por se declarar incapaz de versar assuntos épicos. Com esse expediente, Platão incorpora a epopéia à sua produção literária, subtraindo-a de poetas, na sua opinião imitadores do cotidiano e de sofistas, a quem falta, em virtude de sua condição errante, experiência de ação política concreta. Restam os interlocutores do diálogo pretensamente concluído na véspera, experimentados na vida de uma cidade precisa e exercitados na filosofia, que os ergue a uma posição sobranceira ao vivido: Timeu, cidadão de Locris na Itália, Crítias, ateniense de estirpe antiga e Hermócrates, de conhecida atuação política.

Crítias, ao tomar a palavra, não executa exatamente o que Sócrates pretendia, imaginar operações do exército ideal. Baseado em antigas tradições de família, recorda o que se passou na Atenas de outros tempos. Baseia-se numa versão de origem egípcia, transmitida por Sólon a seu avô. É escrita a fonte egípcia, preservada por razões geológicas favoráveis, diversas das que assolam Atenas. Cataclismos teriam dizimado de tempos em tempos a população de Atenas, reduzindo o estado ao analfabetismo e à perda da memória do que se passara em outros tempos. O documento egípcio teria registrado a grandeza do exército de uma Atenas longínqua, vitoriosa na luta contra o grande exército de uma ilha poderosa, submersa no Oceano, Atlântida. As tropas atenienses, ao invadirem o território da potência inimiga, teriam desaparecido com a ilha, repentinamente.

Recorrendo a uma hipotética fonte escrita, Platão recria a poesia épica em outras bases. A informação já não vem da soberana voz das musas, filhas da Memória. A substância épica é humana desde sua fonte documental, até Crítias, último elo da tradição antiga, homem sem qualidades excepcionais. Assim ela- 
borada, não surpreende que a narrativa não se faça em hexâmetros. Humanizada, a epopéia entra na categoria da opinião, discurso que não requer a adesão por argumentos desenvolvidos com rigor matemático. O diálogo muda de natureza. Fora do enquadramento dialogal, a exposição ocupa o espaço literário. A memória, presa a informantes questionáveis, não é encaminhada a verdades gerais, recuperadas em outros diálogos pela reminiscência. Da maiêutica à carta, Platão ensaia muitas formas literárias. Misturando gêneros, Platão inova. Os diálogos não cabem todos numa mesma categoria.

Crítias interrompe a narrativa para passar a palavra a Timeu, apresentado como geômetra experimentado. Platão apropria-se agora de outra variante épica, a teogonia cosmogônica em que se distinguiram Hesíodo e os órficos. Essa incursão na epopéia já se enquadra nas concepções amadurecidas na República. Depois de ter elaborado a cidade ideal, julga oportuno dar forma às suas concepções cosmológicas sustentadas pelos mesmos princípios. No lugar do colégio dos filósofos, encarregados de propor um modelo às constituições concretas, aparece agora o demiurgo, com os olhos voltados ao mesmo modelo eterno, para organizar o mundo. O demiurgo é literalmente um poietes, um poeta do mundo a desalojar os antigos construtores de teogonias. Os deuses mitológicos são os últimos dos seres eternos criados pelo demiurgo, parcialmente perfeitos, porque inexistentes antes do momento de serem criados. Inferiores ao demiurgo, recebem a incumbência de fabricar os mortais. $O$ homem, o mais perfeito destes, já não aparece como resultado de infração e engano como no mito prometeico, reelaborado por Protágoras. Os deuses conferem aos homens as qualidades adequadas ao funcionamento perfeito do todo. Timeu demora-se na descrição das caraterísticas anatômicas do homem.

Crítias retoma e desenvolve a ficção de Atlântida, o continente desaparecido, o que lhe permite ficcionalizar e idealizar utopicamente o passado de Atenas, de que os atenienses históricos seriam descendentes decaídos. A função hegemônica de Atenas, sublinhada nas duas intervenções de Crítias, lembra o papel que as guerras pérsicas conferiram à orgulhosa potência naval. Saudoso do passado, Platão não perde a esperança de que, sanados os males, nova prosperidade floresça. A invocação das musas, feita por respeito à tradição, não diminui o papel que o documento escrito desempenha no diálogo como um todo e na fala de Crítias em particular. Os seus deuses pacíficos e ordeiros, que se distanciam muito das violentas divindades dos mitos antigos, correspondem à reconstrução da cultura em que Platão denodadamente se empenha. 
Como Timeu nos veio mutilado, somente conjeturas permitem sugerir a continuação da exposição de Crítias e o assunto do anunciado discurso de Hermócrates.

Da união do mythos com o logos, Platão obtém resultados benéficos a ambos. O logos, reduzido ao cálculo, exclui as imprecisões da vida cotidiana impregnada de paixões ou se configura como arma no exercício político de oradores sagazes. Sem o logos, o mythos, rico de experiências vividas, perde a possibilidade de refletir sobre suas bases inseguras, convertendo em dogma o que não é mais que tentativa de acerto. Celebrada a aliança, Platão migra do conhecimento rigoroso (episteme) à conjetura (doxa), além de proporcionar ao pensamento abstrato um campo de operação concreto, as suas obras de ficção, os diálogos. Renovando o espanto diante do mythos, convoca outras estratégias na execução de novo diálogo. Assim, os diálogos não se repetem, avizinhando-se da tragédia, do discurso, da epopéia alternadamente e em diversos graus de proximidade. $\mathrm{O}$ mito, tanto lhe fornece o arcabouço material quanto the abre o caminho da imaginação no lugar em que o logos se detém.

Platão já tem noção elaborada da invenção mítica. Se pensa que Homero inventou nomes como Agamênon e Heitor, que segundo ele traduzem caraterísticas dos heróis a quem são atribuídos, a conclusão de que o pensador nega existência histórica a ambos se impõe. $\mathrm{O}$ poema em que duas personagens centrais se evidenciam como criações poéticas não pode pleitear estatuto de documento apto a recolher o realmente acontecido. Embora negue referencialidade ao poema, o filósofo examina a verdade contida nos nomes. Não quer isso dizer que o mito encerra verdades precisamente por se distanciar de objetualidades identificáveis? Cabendo ao mito dizer o que olhos não vêem, Platão adere ao mito, reflete sobre o mito, e produz mitos. O pensador se comporta como mitólogo não só quando inventa narrativas que se afundam nas origens. Mitos são os seus diálogos enquanto peças inventadas. Míticas são suas personagens, sem excluir Sócrates repetidas vezes reinventado para fins precisos. Preocupações de fidelidade histórica se intrometeriam para embaraçar a exploração de caminhos ainda não trilhados. $O$ espanto encaminha a atenção a regiões que os sentidos não constatam. O espanto sustenta mythos e logos irmanados.

\section{Nota}

* Professor Doutor da Faculdade de Letras da Universidade Federal do Rio Grande do Sul. 


\section{REFERÊNCIAS BibLIOGRÁFICAS}

BACON, F. Novum organon. Nova Atlântida. Tradução de J. A. Reis de Andrade. São Paulo: Victor Civita, 1974.

COMTE, A. Catécisme positiviste. Paris: Larousse, 1890.

CROISET, M. Introduction. In: PLATON. Hippias Mineur, Alcibiade, Apologie de Socrate, Euthyphron, Criton. Paris: Les Belles Lettres, 1953.

DESCARTES, R. Discours de la méthode. Paris: Flammarion, 1930.

HEIDEGGER, M. Holzwege. Frankfurt am Main: Vittorio Klostermann, 1972.

LÉVI-BRUHL, L. La mentalité primitive. Paris: Alcan, 1922.

LÉVI-STRAUSS, C. Antropologie structurale. Paris: Plon, 1958.

NIETZSCHE, F. Die Geburt der Tragoedie. Unzeitgemässe Betrachtungen I-IV. Nachgelassene Schriften 1870-1873. München: de Gruyter, 1988.

PLATON. Cratyle. Texte établi et traduit par L. Méridier. Paris: Les Belles Lettres, 1950. 1955.

. Le sophiste. Texte établi et traduit par A. Diès. Paris: Le Belles Lettres, . Timée. Crítias. Texte établi et traduit par A. Rivaud. Paris: Les Belles Lettres, 1956.

TAMINIAUX, J. Le théâtre des philosophes. Grenoble: Millon, 1995.

TORRANO, Jaa. O sentido de Zeus. São Paulo: Iluminuras, 1996.

TUSELL, N. A. Origen y decadencia del logos. Barcelona: Anthropos, 1993.

ZELLER, E. Die philosophie der Griechen in ihrer geschichtlichen Entwicklung. Darmstadt: Wissentschaftliche Buchgesellschaft, 1963.

SCHÜLER, Donaldo. Mythos and logos in Platonic dialogue.

ABSTRACT: In opposition to what one thought during the last century, mythos and logos may live in the same time and in the same space. There are irrational moments in the realm of myth, notwithstanding one ought not to suppose it contrary to logical preoccupations, if we consider genealogies and the structure of mythical stories. Myth is not a discorder according to Heracleitus; it is an other order. The Sophists liberate discourse (logos) from nature (physis). Plato withdraws discourse from the autority of the speaker. Platonic myth renews the art os speaking.

KEYWORDS: mythos; logos; dialogue; Sophists; Heracleitus; Plato. 